\title{
Efficacy and safety of dual blockade of the renin-angiotensin system: meta-analysis of randomised trials
}

\author{
(c) $\frac{(1)(8)}{\text { ay }}$ OPEN ACCESS
}

\author{
Harikrishna Makani fellow in cardiovascular medicine ${ }^{1}$, Sripal Bangalore director of cardiovascular \\ outcomes group, assistant professor of medicine ${ }^{2}$, Kavit A Desouza fellow in cardiovascular

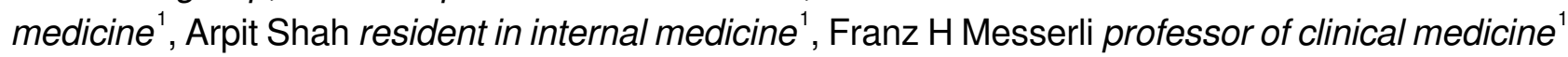

'Division of Cardiology, St Luke's Roosevelt Hospital, Columbia University College of Physicians and Surgeons, 1000 10th Avenue, New York, NY 10019, USA; ${ }^{2}$ The Leon H Charney Division of Cardiology, New York University School of Medicine, New York, NY, USA

\begin{abstract}
Objective To compare the long term efficacy and adverse events of dual blockade of the renin-angiotensin system with monotherapy.

Design Systematic review and meta-analysis.

Data sources PubMed, Embase, and the Cochrane central register of controlled trials, January 1990 to August 2012.

Study selection Randomised controlled trials comparing dual blockers of the renin-angiotensin system with monotherapy, reporting data on either long term efficacy ( $\geq 1$ year) or safety events ( $\geq 4$ weeks), and with a sample size of at least 50 . Analysis was stratified by trials with patients with heart failure versus patients without heart failure.

Results 33 randomised controlled trials with 68405 patients (mean age 61 years, $71 \%$ men) and mean duration of 52 weeks were included. Dual blockade of the renin-angiotensin system was not associated with any significant benefit for all cause mortality (relative risk $0.97,95 \%$ confidence interval 0.89 to 1.06$)$ and cardiovascular mortality $(0.96,0.88$ to 1.05) compared with monotherapy. Compared with monotherapy, dual therapy was associated with an $18 \%$ reduction in admissions to hospital for heart failure $(0.82,0.74$ to 0.92$)$. However, compared with monotherapy, dual therapy was associated with a $55 \%$ increase in the risk of hyperkalaemia $(\mathrm{P}<0.001)$, a $66 \%$ increase in the risk of hypotension $(P<0.001)$, a $41 \%$ increase in the risk of renal failure $(\mathrm{P}=0.01)$, and a $27 \%$ increase in the risk of withdrawal owing to adverse events $(P<0.001)$. Efficacy and safety results were consistent in cohorts with and without heart failure when dual therapy was compared with monotherapy except for all cause mortality, which was higher in the cohort without heart failure $(\mathrm{P}=0.04 v \mathrm{P}=0.15)$, and renal failure was significantly higher in the cohort with heart failure $(\mathrm{P}<0.001 v \mathrm{P}=0.79)$.
\end{abstract}

Conclusion Although dual blockade of the renin-angiotensin system may have seemingly beneficial effects on certain surrogate endpoints, it failed to reduce mortality and was associated with an excessive risk of adverse events such as hyperkalaemia, hypotension, and renal failure compared with monotherapy. The risk to benefit ratio argues against the use of dual therapy.

\section{Introduction}

The concept of dual blockade of the renin-angiotensin system originated from an experimental model ${ }^{1}$ purporting to show a "synergistic" effect between angiotensin converting enzyme (ACE) inhibitors and angiotensin receptor blockers. The concept seemed so logical and appealing that seemingly beneficial changes in surrogate endpoints such as blood pressure, proteinuria, and endothelial dysfunction became accepted as a free pass for dual blockade having cardioprotective and nephroprotective effects. Despite a lack of solid evidence on the safety and efficacy of dual blockade of the renin-angiotensin system this type of therapy has been mentioned in several sets of guidelines..$^{2-4}$ Thus dual therapy was commonly used in patients with hypertension and with diabetes or proteinuria, or both and also to a lesser extent in those with heart failure resistant to treatment. Even patients with uncomplicated essential hypertension were not entirely able to escape this fashionable trend. In the United States more than 200000 patients are currently treated with dual blockade of the renin-angiotensin system, most of them by the combination of an angiotensin receptor blocker and ACE inhibitor $(70 \%) .{ }^{5}$ Some other combinations are also used, such as two ACE inhibitors (15\%), two angiotensin receptor blockers (5\%), and ACE inhibitors or 
angiotensin receptor blockers in combination with a direct renin inhibitor $(8 \%){ }^{5}$ The long term efficacy and safety of dual blockade is not, however, well defined.

We compared the long term efficacy of dual blockade of the renin-angiotensin system (any two of ACE inhibitors, angiotensin receptor blockers, or aliskiren) with monotherapy and evaluated adverse events in patients receiving dual therapy compared with monotherapy.

\section{Methods}

We systematically searched PubMed, Embase, and the Cochrane central register of controlled trials (Cochrane Library Issue 6, June 2012) using the key terms "ACE inhibitors", "angiotensin receptor blockers", "direct renin inhibitors" and using the names of individual drugs (see supplementary table 1). The search was restricted to randomised controlled trials in humans and in peer reviewed journals from 1990 to August 2012. No language restriction was applied. We checked the reference lists of the reviewed articles and original studies identified by the electronic search for other potentially eligible articles.

\section{Study selection and data extraction}

Two authors (KD and AS) searched the data independently and in duplicate. Disagreements were resolved by consensus. For this analysis we extracted the year of publication, baseline characteristics of the study population, sample size, type of drug, mean age, study duration, percentage of men, long term efficacy (all cause mortality, cardiovascular mortality, and admissions to hospital for heart failure), and safety events (hyperkalaemia, hypotension, renal failure, and withdrawal owing to drug related adverse events). Hyperkalaemia was defined in the included studies as a serum concentration of potassium greater than $5.5 \mathrm{mmol} / \mathrm{L}$ and renal failure as a serum creatinine concentration greater than $176.8 \mu \mathrm{mol} / \mathrm{L}(>2.0 \mathrm{mg} / \mathrm{dL})$ or a doubling of baseline serum creatinine level. The definition of hypotension in the studies varied from symptomatic hypotension to evidence of low blood pressure. Withdrawal owing to drug related adverse events was defined as withdrawal by a patient as a result of any of the clinical or biochemical adverse events.

\section{Selection criteria}

We screened the trials for eligibility using the following criteria: randomised clinical trials comparing individual blockers with a combination of blockers (ACE inhibitor, angiotensin receptor blocker, or direct renin inhibitor), data on either long term efficacy (duration $\geq 1$ year) or safety events (duration $\geq 4$ weeks), and a sample size of at least 50 . Given the limited number of trials reporting data on stroke and myocardial infarction, these outcomes were not evaluated in the study.

\section{Quality assessment}

The criteria used for quality assessment were sequence generation of allocation; allocation concealment; masking of participants, staff, and outcome assessors; incomplete outcome data; selective outcome reporting; and other sources of bias, as recommended by the Cochrane Collaboration. ${ }^{7}$ We classed studies with high or unclear risk of bias for any of the first three components to be of low quality.

\section{Statistical analysis}

The statistical analysis was done in line with recommendations from the Cochrane Collaboration and the preferred reporting items for systematic reviews and meta-analyses (PRISMA) guidelines $^{8}$ using Review Manager (RevMan), version 5.1.7 (Cochrane Collaboration, 2012). Heterogeneity was assessed using the $\mathrm{I}^{2}$ statistic. $\mathrm{I}^{2}$ is the proportion of total variation observed between the trials attributable to differences between trials rather than to sampling error (chance), and we considered $\mathrm{I}^{2}<25 \%$ as representing low heterogeneity and $\mathrm{I}^{2}>75 \%$ as representing high heterogeneity. We used the random effects model of DerSimonian and Laird ${ }^{9}$ to calculate the effect sizes because of known clinical and methodological heterogeneity of the studies. All analyses were performed using the intention to treat principle. Results were calculated by relative risk ratio and 95\% confidence intervals using the Mantel-Haenszel method. We carried out head to head comparisons between individual blockers and the combination of blockers for both long term efficacy and safety data. Analysis was stratified by patient cohorts with and without heart failure. Analysis was also done to evaluate the safety outcomes between dual blockers (ACE inhibitors+angiotensin receptor blockers, angiotensin receptor blockers+aliskiren, ACE inhibitors+aliskiren) and individual blockers.

Publication bias was estimated visually by funnel plots ${ }^{10}$ or by Begg's test and the weighted regression test of Egger. ${ }^{11}$ If there was evidence of publication bias, we applied the trim and fill method to adjust the results of the meta-analysis. ${ }^{12}$

\section{Sensitivity analysis}

Sensitivity analysis was performed for safety outcomes based on the cohort of patients with heart failure versus the cohort without, risk of bias in the trial (low $v$ high), duration of follow-up ( $<1$ year $v \geq 1$ year), and number of patients $(<500 v$ $\geq 500$ ). We used a test for interaction to estimate differences between the subgroups. ${ }^{13}$ Sensitivity analysis was not done for long term efficacy outcomes because of the limited number of studies available.

\section{Results}

A total of 138 full text articles were assessed for eligibility, of which 33 met the inclusion criteria (fig $1 \Downarrow$ ). The 33 trials $^{14-46}$ enrolled 68405 patients with a mean age of 61 (SD 4) years, $71 \%$ men, followed-up for a mean duration of 52 weeks (table $1 \Downarrow$ ). A combination of an ACE inhibitor and angiotensin receptor blocker was used in 22 trials, ${ }^{14-35}$ an ACE inhibitor and aliskiren in three trials, ${ }^{36-38}$ an angiotensin receptor blocker and aliskiren in seven trials, ${ }^{39-45}$ and an ACE inhibitor or angiotensin receptor blocker with aliskiren in one trial. ${ }^{46}$

Efficacy data were available from seven trials with a total of 56 824 patients (mean age 65 (SD 2) years, $72 \%$ males) and mean duration of 2.7 years. Safety data were available from all of the included trials.

Of the 33 trials, 18 reported adequate generation of allocation sequence and adequate allocation concealment and 24 reported adequate masking of participants, staff, and outcome assessors. On the basis of quality assessment, 18 were deemed to be at low risk of bias and the remainder to be at high risk.

\section{Dual therapy versus monotherapy: efficacy outcomes}

\section{All cause mortality}

Data were available from seven trials with a total of 56824 patients. Overall, 3314 of 21638 patients $(15.3 \%)$ died in the dual therapy group compared with 5286 of 35186 patients $(15.0 \%)$ in the monotherapy group. When compared with 
monotherapy alone, dual therapy had no benefit on all cause mortality (relative risk $0.97,95 \%$ confidence interval 0.89 to $1.06, \mathrm{P}=0.50, \mathrm{I}^{2}=69 \%$, fig $\left.2 \Downarrow\right)$.

In subgroup analysis, dual therapy showed no benefit for all cause mortality in the cohort with heart failure $(0.92,0.82$ to $1.03, \mathrm{P}=0.15)$, however mortality was increased in the cohort without heart failure $(1.07,1.00$ to $1.14, \mathrm{P}=0.04$, fig 2$)$. The difference between these two subgroups was significant $(\mathrm{P}=0.02)$.

\section{Cardiovascular mortality}

In six trials 2812 of 19127 patients (14.7\%) died of cardiovascular causes in the dual therapy group compared with 5128 of 32687 patients $(15.7 \%)$ in the monotherapy group. Dual therapy had no significant benefit on cardiovascular mortality $\left(0.96,0.88\right.$ to $1.05, \mathrm{P}=0.38, \mathrm{I}^{2}=59 \%$, fig $\left.3 \Downarrow\right)$ compared with monotherapy.

In subgroup analysis, dual therapy had no benefit on cardiovascular mortality in the cohorts both with heart failure $(\mathrm{P}=0.14)$ and without $(\mathrm{P}=0.61)$.

\section{Admissions to hospital for heart failure}

In five trials 1825 of 16728 patients $(10.9 \% 0$ in the dual therapy group were admitted to hospital for heart failure compared with 2604 of 25343 patients (10.3\%) in the monotherapy group.

Dual therapy was associated with a $18 \%$ reduction in admissions to hospital for heart failure compared with monotherapy $(0.82$, 0.74 to $0.92, \mathrm{I}^{2}=68 \%, \mathrm{P}=0.0003$, fig $\left.4 \Downarrow\right)$. This was largely driven by a benefit in the cohort with heart failure $(0.77,0.68$ to 0.88 , $\mathrm{P}=0.0001$ ), although there was a trend towards benefit in the cohort without heart failure $(0.91,0.82$ to $1.01, \mathrm{P}=0.07)$.

\section{Dual therapy versus monotherapy: safety outcomes}

\section{Hyperkalaemia}

In 23 trials 2188 of 22717 patients $(9.6 \%)$ had hyperkalaemia in the dual therapy group compared with 1887 of 37921 patients $(4.9 \%)$ in the monotherapy group. Dual therapy was associated with a $55 \%$ increased risk of hyperkalaemia $(1.55,1.32$ to 1.82 , $\mathrm{I}^{2}=50 \%, \mathrm{P}<0.001$, fig $\left.5 \Downarrow\right)$ compared with monotherapy.

In subgroup analysis, the risk of hyperkalaemia increased significantly in both the cohort with heart failure $(\mathrm{P}=0.02)$ and the cohort without $(\mathrm{P}<0.001)$.

\section{Hypotension}

In 18 trials 2042 of 23572 patients (8.7\%) had hypotension in the dual therapy group compared with 2227 of 37680 patients $(5.9 \%)$ in the monotherapy group. Dual therapy was associated with a $66 \%$ increased risk of hypotension (1.66 1.38 to 1.98 , $\mathrm{I}^{2}=66 \%, \mathrm{P}<0.001$, fig $\left.6 \Downarrow\right)$ compared with monotherapy.

In subgroup analysis, the risk of hypotension increased significantly in the cohorts both with heart failure $(\mathrm{P}<0.001)$ and without $(\mathrm{P}=0.002)$.

\section{Renal failure}

In 20 trials 2026 of 24536 patients (8.3\%) had renal failure in the dual therapy group compared with 2551 of 39784 patients $(6.4 \%)$ in the monotherapy group. Dual therapy was associated with a $41 \%$ increased risk of renal failure $(1.41,1.09$ to 1.84 , $\mathrm{I}^{2}=83 \%, \mathrm{P}=0.01$, fig $7 \Downarrow$ ) compared with monotherapy.
$\mathrm{P}<0.001)$ but not in the cohort without $(1.04,0.80$ to 1.35 , $\mathrm{P}=0.76)$. The difference between these two subgroups was significant $(\mathrm{P}<0.001)$.

\section{Withdrawal owing to drug related adverse events}

In 26 trials 4265 of 24994 patients (17.1\%) had withdrawal owing to drug related adverse events in the dual therapy group compared with 5825 of 40247 patients $(14.5 \%)$ in the monotherapy group. Dual therapy was associated with a $27 \%$ increase in the risk of withdrawal owing to drug related adverse events $\left(1.27,1.21\right.$ to $1.32, \mathrm{I}^{2}=2 \%, \mathrm{P}<0.001$, fig $\left.8 \Downarrow\right)$ compared with monotherapy.

In subgroup analysis, the risk of withdrawal owing to drug related adverse events increased significantly in the cohort both with heart failure $(\mathrm{P}<0.001)$ and without $(\mathrm{P}=0.0003)$.

\section{Subgroup analysis of safety outcomes}

Comparing the combination of ACE inhibitors and angiotensin receptor blockers with ACE inhibitors alone, the risk of all safety outcomes (hyperkalaemia, hypotension, renal failure, and withdrawal owing to drug related adverse events) increased significantly with combination treatment: (table $2 \Downarrow$ ). Comparing the combination of ACE inhibitors and angiotensin receptor blockers with angiotensin receptor blockers alone, the risk of hypotension and withdrawal owing to drug related adverse events increased significantly but not the risk of hyperkalaemia and renal failure with combination treatment (table 2). Comparing the combination of ACE inhibitors and aliskiren with ACE inhibitors alone, the risk of hyperkalaemia and hypotension increased significantly but there was no difference in the risk of renal failure and withdrawal owing to drug related adverse events with combination treatment (table 2). Comparing the combination of ACE inhibitors and aliskiren with aliskiren alone, the risk of hyperkalaemia, hypotension, renal failure, and withdrawal owing to drug related adverse effects did not differ with combination treatment (table 2). Comparing the combination of angiotensin receptor blockers and aliskiren with angiotensin receptor blockers alone, the risk of hyperkalaemia was increased significantly but there was no difference in the risk of other adverse events (table 2). Comparing the combination of angiotensin receptor blockers and aliskiren with aliskiren alone, none of the adverse events differed significantly between the two groups (table 2). These subgroup analyses are presented as forest plots in supplementary figures 1-4.

Sensitivity analyses did not show any significant difference in the groups for hyperkalaemia, hypotension, or withdrawal owing to drug related adverse effects. The risk of renal failure was significantly higher in the cohort of patients with heart failure compared with the cohort without heart failure $(\mathrm{P}<0.001$, see supplementary table 2).

Significant heterogeneity was present in most of the analyses. Thus a random variance model was used. No evidence of publication bias was suggested by visual inspection of funnel plots or by Egger's test. The results were not significantly different after applying the trim and fill method all cause mortality (relative risk $0.94,95 \%$ confidence interval 0.86 to $1.03)$, cardiovascular mortality ( $0.96,0.86$ to 1.04$)$, admissions to hospital for heart failure $(0.82,0.74$ to 0.91$)$, hyperkalaemia (1.44, 1.22 to 1.70$)$, hypotension $(1.59,1.33$ to 1.91$)$, renal failure $(1.47,1.13$ to 1.92$)$, and withdrawal owing to drug related adverse events $(1.27,1.20$ to 1.34$)$ (see supplementary figure 5). 


\section{Discussion}

The present analysis evaluating the long term efficacy and safety of dual blockade of the renin-angiotensin system failed to show any benefit for all cause mortality and cardiovascular mortality with dual therapy compared with monotherapy. This is the most comprehensive review of literature evaluating both the safety and outcomes of dual therapy. Although compared with monotherapy dual therapy was associated with a reduction in admissions to hospital for heart failure mainly in the cohort with heart failure, the risks of hyperkalaemia, hypotension, renal failure, and withdrawal owing to drug related adverse events were significantly increased. Given these facts it may appropriately be asked why dual therapy was and still is extensively used to treat many patients with hypertension and heart failure. With the exception of the CHARM Added trial, ${ }^{18}$ most if not all data making dual therapy attractive are based on evidence from surrogate endpoints.

One meta-analysis ${ }^{47}$ reported "encouraging" evidence that dual therapy reduced proteinuria by an incremental 20-25\% compared with monotherapy. The COOPERATE study ${ }^{48}$ even showed that dual therapy with trandolapril and losartan reduced the risk of the primary endpoint (time to doubling of serum creatinine level or end stage renal disease) by $60 \%$ better than monotherapy, thereby becoming one of the most widely quoted studies by the Lancet ${ }^{49}$ After such seemingly robust evidence many physicians accepted that reduction of albuminuria or proteinuria was synonymous with nephroprotection. In the CHARM Added trial, ${ }^{18}$ in a cohort of 2548 patients with heart failure, dual blockade of the renin-angiotensin system (candesartan and ACE inhibitor) significantly reduced the primary outcome of cardiovascular death or admission to hospital for worsening of heart failure. As a consequence, dual therapy became more and more used in patients with hypertension, diabetes, and heart failure resistant to treatment.

The importance of dual therapy began to change with publication of the Ongoing Telmisartan Alone and in Combination with Ramipril Global Endpoint Trial (ONTARGET).$^{50}$ Similar to other studies, in this study the surrogate endpoint albuminuria was reduced with dual therapy compared with monotherapy. However, a significant doubling of creatinine level and dialysis in the combination arm (despite less albuminuria) argued against a nephroprotection by dual therapy. More recently, authors ${ }^{51}$ found several inconsistencies in COOPERATE, eventually leading to retraction of the study by the Lancet $^{52}$

In heart failure, the safety issue remained a major concern with dual therapy. In the CHARM Added trial, hyperkalaemia was almost five times more common and increased creatinine levels twice as common with dual therapy than with monotherapy. A meta-analysis $^{53}$ in over 18000 patients with left ventricular dysfunction showed a significantly increased risk of adverse events of dual therapy compared with monotherapy, leading to the discontinuation of dual therapy. Given the adverse effects and lack of consistent survival benefits, the addition of an angiotensin receptor blocker to ACE inhibitor therapy in patients with heart failure should perhaps be reserved only for selected patients who continue to have symptoms while receiving monotherapy and cannot tolerate mineralocorticoid antagonists.

Several trials have shown a beneficial effect of aliskiren in combination with ACE inhibitors or angiotensin receptor blockers in patients with heart failure or diabetic nephropathy on surrogate endpoints, such as in proteinuria ${ }^{41}$ left ventricular hypertrophy, ${ }^{39}$ and neurohormonal changes. ${ }^{36}$ Our analysis showed a significantly increased risk of hyperkalaemia with combination therapy with aliskiren compared with monotherapy.
Similar results were also found in a recent meta-analysis of 10 studies with over 4800 patients. ${ }^{54}$ The ALTITUDE trial ${ }^{46}$ was terminated early because of an increased risk of adverse outcomes (stroke, hypotension, and hyperkalaemia) when aliskiren was combined with ACE inhibitors or angiotensin receptor blockers. As to the mechanism of hypotension, one author suggested that blockade of the renin-angiotensin-aldosterone system could trigger the Bezold-Jarisch reflex sensitised by withdrawal of the effect of angiotensin II..$^{55}$ More extensive blockade of the renin-angiotensin system with two drugs could lead to a reduction in sympathetic outflow from the brainstem and excessive vagal tone causing prolonged hypotension and bradycardia. Conceivably this mechanism might account for the higher incidence of stroke and hypotension in patients receiving dual therapy. ${ }^{55}$ Regulatory agencies such as the Food and Drug Administration and European Medicines Agency ${ }^{56}$ recommended avoiding aliskiren in patients with diabetes or moderate to severe renal dysfunction who are already taking ACE inhibitors or angiotensin receptor blockers. Of note, the VA NEPHRON-D multicentre trial ${ }^{57}$ to assess the effect of combination of losartan and lisinopril compared with losartan alone, on the progression of kidney disease in 1850 patients with diabetes and overt proteinuria was terminated recently for similar reasons to those of ALTITUDE.

The present data evolving from studies with dual blockade of the renin-angiotensin system should be a reminder hat many purported benefits of such therapy was solely based on data using surrogate endpoints. Surrogate endpoints not uncommonly fail to emulate hard outcomes endpoints and leapfrogging from surrogate data cannot substitute for the exposure of patients in clinical outcome studies.

\section{Strengths and limitations of this meta-analysis}

Our paper had several limitations. As with other meta-analyses, given the lack of data in each trial, we did not adjust our analysis for adherence to therapy. Also, the results are subject to limitations inherent to any meta-analysis based on pooling of data from different trials with different duration, doses of drugs, definitions for safety outcomes, and patient groups. Analysis of safety events is also prone to several biases since the data vary in each study for quality, incidence, severity, and adjudication. The reporting may also be influenced by expectations of the investigators, sponsors, and patients. Despite all the limitations, this is the most comprehensive analysis evaluating the safety and efficacy of dual blockade of the renin-angiotensin system. Despite significant heterogeneity among the studies, there was no evidence of publication bias visually and by Egger's test. The results were fairly consistent among various subgroups.

\section{Conclusion}

Although dual blockade of the renin-angiotensin system may have seemingly beneficial effects on certain surrogate endpoints, it failed to reduce mortality and was associated with an excessive risk of adverse events such as hyperkalaemia, hypotension, and renal failure when compared with monotherapy. The overall risk to benefit ratio argues against the use of dual therapy.

Contributors: HM supervised the study, had full access to all the data in the study, and takes responsibility for the integrity of the data and the accuracy of the data analysis. He is the guarantor. HM, SB, and FHM conceived and designed the study, acquired the data, drafted the 


\section{What is already known on this topic}

Dual blockade of the renin-angiotensin system (RAS) is extensively used for treatment of resistant forms of heart failure, hypertension, diabetic nephropathy, and proteinuria

The efficacy and safety of dual RAS blockade, however, remains controversial

\section{What this study adds}

Although dual RAS blockade reduced admissions to hospital for heart failure (mainly in patients with heart failure), it had no effect on all cause or cardiovascular mortality

Compared with monotherapy, dual therapy was associated with a significant increase in adverse events such as hyperkalaemia, hypotension, and renal failure

These considerations of risk-benefit argue against the routine use of dual therapy

manuscript, and critically revised the manuscript for important intellectual content. KAD and AS analysed and interpreted the data. All authors carried out the statistical analysis and had full access to all the data in the study.

Funding: This research received no specific grant from any funding agency in the public, commercial, or not for profit sectors. None of the authors received any compensation for their work on this manuscript.

Competing interests: All authors have completed the ICMJE uniform disclosure form at www.icmje.org/coi_disclosure.pdf (available on request from the corresponding author) and declare: FHM is an ad hoc consultant and speaker for Novartis, Daiichi Sankyo, Pfizer, Takeda, Abbott, Medtronic, Servier, and Bayer; SB is on the advisory board of Daiichi Sankyo and Boehringer Ingelheim; no financial relationships with any organisations that might have an interest in the submitted work in the previous three years; and no other relationships or activities that could appear to have influenced the submitted work.

Ethical approval: Not required.

Data sharing: No additional data available.

Menard J, Campbell DJ, Azizi M, Gonzales MF. Synergistic effects of ACE inhibition and Ang II antagonism on blood pressure, cardiac weight, and renin in spontaneously hypertensive rats. Circulation 1997;96:3072-8.

2 Jessup M, Abraham WT, Casey DE, Feldman AM, Francis GS, Ganiats TG, et al. 2009 focused update: ACCF/AHA Guidelines for the Diagnosis and Management of Heart Failure in Adults: a report of the American College of Cardiology Foundation/American Heart Association Task Force on Practice Guidelines: developed in collaboration with the International Society for Heart and Lung Transplantation. Circulation 2009;119:1977-2016.

3 McMurray JJ, Adamopoulos S, Anker SD, Auricchio A, Bohm M, Dickstein K, et al. ESC guidelines for the diagnosis and treatment of acute and chronic heart failure 2012: the Task Force for the Diagnosis and Treatment of Acute and Chronic Heart Failure 2012 of the European Society of Cardiology. Developed in collaboration with the Heart Failure Association (HFA) of the ESC. Eur Heart J 2012;14:803-69.

4 Standards of medical care in diabetes-2012. Diabetes Care 2012;35(Suppl 1):S11-63. 5 Banerjee S, Kaye S. The role of targeted therapy in ovarian cancer. Eur $J$ Cancer 2011:47(Suppl 3):S116-30.

6 Messerli FH, Staessen JA, Zannad F. Of fads, fashion, surrogate endpoints and dual RAS blockade. Eur Heart J 2010;31:2205-8.

7 Higgins J, Green S. Assessing risk of bias in included studies. Cochrane handbook for systematic reviews of interventions version 5.0.0 edn. Oxford: Cochrane Collaboration. 2008:672.

8 Moher D, Liberati A, Tetzlaff J, Altman DG. Preferred reporting items for systematic reviews and meta-analyses: the PRISMA statement. BMJ 2009;339:b2535.

9 DerSimonian R, Laird N. Meta-analysis in clinical trials. Control Clin Trials 1986;7:177-88.

10 Sterne JA, Sutton AJ, loannidis JP, Terrin N, Jones DR, Lau J, et al. Recommendations for examining and interpreting funnel plot asymmetry in meta-analyses of randomised controlled trials. BMJ 2011;343:d4002.

11 Egger M, Davey Smith G, Schneider M, Minder C. Bias in meta-analysis detected by a simple, graphical test. BMJ 1997;315:629-34.

12 Duval S, Tweedie R. Trim and fill: a simple funnel-plot-based method of testing and adjusting for publication bias in meta-analysis. Biometrics 2000;56:455-63.

13 Altman DG, Bland JM. Interaction revisited: the difference between two estimates. BMJ 2003;326:219.

14 Izzo JL Jr, Weinberg MS, Hainer JW, Kerkering J, Tou CK. Antihypertensive efficacy of candesartan-lisinopril in combination vs. up-titration of lisinopril: the AMAZE trials. J Clin Hypertens (Greenwich) 2004:6:485-93.

15 Azizi M, Linhart A, Alexander J, Goldberg A, Menten J, Sweet C, et al. Pilot study of combined blockade of the renin-angiotensin system in essential hypertensive patients. $J$ Hypertens 2000;18:1139-47.

16 Mogensen CE, Neldam S, Tikkanen I, Oren S, Viskoper R, Watts RW, et al. Randomised controlled trial of dual blockade of renin-angiotensin system in patients with hypertension, microalbuminuria, and non-insulin dependent diabetes: the candesartan and lisinopril microalbuminuria, and non-insulin dependent diabetes:

17 Andersen NH, Poulsen PL, Knudsen ST, Poulsen SH, Eiskjaer H, Hansen KW, et al. Long-term dual blockade with candesartan and lisinopril in hypertensive patients with diabetes: the CALM II study. Diabetes Care 2005;28:273-7.

18 McMurray JJ, Ostergren J, Swedberg K, Granger CB, Held P, Michelson EL, et al. Effects of candesartan in patients with chronic heart failure and reduced left-ventricular systolic function taking angiotensin-converting-enzyme inhibitors: the CHARM-Added trial. Lancet 2003;362:767-71.

19 Cice G, Di Benedetto A, D'Isa S, D'Andrea A, Marcelli D, Gatti E, et al. Effects of telmisartan added to angiotensin-converting enzyme inhibitors on mortality and morbidity in hemodialysis patients with chronic heart failure a double-blind, placebo-controlled trial. J Am Coll Cardiol 2010;56:1701-8.

20 Bakris GL, Ruilope L, Locatelli F, Ptaszynska A, Pieske B, de Champlain J, et al. Treatment of microalbuminuria in hypertensive subjects with elevated cardiovascular risk: results of the IMPROVE trial. Kidney Int 2007;72:879-85.

21 Kanno Y, Takenaka T, Nakamura T, Suzuki H. Add-on angiotensin receptor blocker in patients who have proteinuric chronic kidney diseases and are treated with angiotensin-converting enzyme inhibitors. Clin J Am Soc Nephrol 2006;1:730-7.

22 Kum LC, Yip GW, Lee PW, Lam YY, Wu EB, Chan AK, et al. Comparison of angiotensin-converting enzyme inhibitor alone and in combination with irbesartan for the treatment of heart failure. Int J Cardiol 2008;125:16-21.

23 Mehdi UF, Adams-Huet B, Raskin P, Vega GL, Toto RD. Addition of angiotensin recepto blockade or mineralocorticoid antagonism to maximal angiotensin-converting enzyme inhibition in diabetic nephropathy. J Am Soc Nephrol 2009;20:2641-50.

24 Ogawa S, Takeuchi K, Mori T, Nako K, Tsubono Y, Ito S. Effects of monotherapy of temocapril or candesartan with dose increments or combination therapy with both drugs on the suppression of diabetic nephropathy. Hypertens Res 2007;30:325-34.

25 Yusuf S, Teo KK, Pogue J, Dyal L, Copland I, Schumacher H, et al. Telmisartan, ramipril, or both in patients at high risk for vascular events. N Engl J Med 2008;358:1547-59.

26 McKelvie RS, Yusuf S, Pericak D, Avezum A, Burns RJ, Probstfield J, et al. Comparison of candesartan, enalapril, and their combination in congestive heart failure: randomized evaluation of strategies for left ventricular dysfunction (RESOLVD) pilot study. The RESOLVD Pilot Study Investigators. Circulation 1999;100:1056-64.

27 Ruilope LM, Aldigier JC, Ponticelli C, Oddou-Stock P, Botteri F, Mann JF. Safety of the combination of valsartan and benazepril in patients with chronic renal disease. European Group for the Investigation of Valsartan in Chronic Renal Disease. J Hypertens 2000;18:89-95.

28 Titan SM, M Vieira J Jr, Dominguez WV, Barros RT, Zatz R. ACEI and ARB combination therapy in patients with macroalbuminuric diabetic nephropathy and low socioeconomic level: a double-blind randomized clinical trial. Clin Nephrol 2011;76:273-83.

29 Tonkon M, Awan N, Niazi I, Hanley P, Baruch L, Wolf RA, et al. A study of the efficacy and safety of irbesartan in combination with conventional therapy, including ACE inhibitors, in heart failure. Irbesartan Heart Failure Group. Int J Clin Pract 2000;54:11-4, 16-8.

30 Menne J, Farsang C, Deak L, Klebs S, Meier M, Handrock R, et al. Valsartan in combination with lisinopril versus the respective high dose monotherapies in hypertensive patients with microalbuminuria: the VALERIA trial. $J$ Hypertens 2008;26:1860-7.

31 Cohn JN, Tognoni G. A randomized trial of the angiotensin-receptor blocker valsartan in chronic heart failure. N Engl J Med 2001;345:1667-75.

32 Baruch L, Anand I, Cohen IS, Ziesche S, Judd D, Cohn JN. Augmented short- and long-term hemodynamic and hormonal effects of an angiotensin receptor blocker added to angiotensin converting enzyme inhibitor therapy in patients with heart failure. Vasodilator Heart Failure Trial (V-HeFT) Study Group. Circulation 1999;99:2658-64.

33 Pfeffer MA, McMurray JJ, Velazquez EJ, Rouleau JL, Kober L, Maggioni AP, et al. Valsartan, captopril, or both in myocardial infarction complicated by heart failure, left ventricular dysfunction, or both. N Engl J Med 2003;349:1893-906.

34 White M, Lepage S, Lavoie J, De Denus S, Leblanc MH, Gossard D, et al. Effects of combined candesartan and ACE inhibitors on BNP, markers of inflammation and oxidative stress, and glucose regulation in patients with symptomatic heart failure. J Card Fail 2007;13:86-94.

35 Yasumura Y, Miyatake K, Okamoto H, Miyauchi T, Kawana M, Tsutamoto T, et al. Rationale for the use of combination angiotensin-converting enzyme inhibitor and angiotensin II receptor blocker therapy in heart failure. Circ J 2004;68:361-6.

36 McMurray JJ, Pitt B, Latini R, Maggioni AP, Solomon SD, Keefe DL, et al. Effects of the oral direct renin inhibitor aliskiren in patients with symptomatic heart failure. Circ Heart Fail 2008;1:17-24.

37 Solomon SD, Shin SH, Shah A, Skali H, Desai A, Kober L, et al. Effect of the direct renin inhibitor aliskiren on left ventricular remodelling following myocardial infarction with systolic dysfunction. Eur Heart J 2011:32:1227-34.

38 Uresin Y, Taylor AA, Kilo C, Tschope D, Santonastaso M, Ibram G, et al. Efficacy and safety of the direct renin inhibitor aliskiren and ramipril alone or in combination in patients with diabetes and hypertension. J Renin Angiotensin Aldosterone Syst 2007;8:190-8.

39 Solomon SD, Appelbaum E, Manning WJ, Verma A, Berglund T, Lukashevich V, et al. Effect of the direct renin inhibitor aliskiren, the angiotensin receptor blocker losartan, or both on left ventricular mass in patients with hypertension and left ventricular hypertrophy. Circulation 2009;119:530-7.

40 Scirica BM, Morrow DA, Bode C, Ruzyllo W, Ruda M, Oude Ophuis AJ, et al. Patients with acute coronary syndromes and elevated levels of natriuretic peptides: the results of the AVANT GARDE-TIMI 43 Trial. Eur Heart J 2010;31:1993-2005.

41 Parving HH, Persson F, Lewis JB, Lewis EJ, Hollenberg NK. Aliskiren combined with losartan in type 2 diabetes and nephropathy. N Engl J Med 2008;358:2433-46. 
42 Drummond W, Sirenko YM, Ramos E, Baek I, Keefe DL. Aliskiren as add-on therapy in the treatment of hypertensive diabetic patients inadequately controlled with valsartan/HCT combination: a placebo-controlled study. Am J Cardiovasc Drugs 2011;11:327-33.

43 Oparil S, Yarows SA, Patel S, Fang H, Zhang J, Satlin A. Efficacy and safety of combined use of aliskiren and valsartan in patients with hypertension: a randomised, double-blind trial. Lancet 2007;370:221-9.

44 Pool JL, Schmieder RE, Azizi M, Aldigier JC, Januszewicz A, Zidek W, et al. Aliskiren, an orally effective renin inhibitor, provides antihypertensive efficacy alone and in combination with valsartan. Am J Hypertens 2007;20:11-20.

45 Piao JM, Kim HN, Song HR, Kweon SS, Choi JS, Yoon JY, et al. p53 codon 72 polymorphism and the risk of esophageal cancer: a Korean case-control study. Dis Esophagus 2011;24:596-600.

46 Parving HH, Brenner BM, McMurray JJ, de Zeeuw D, Haffner SM, Solomon SD, et al. Cardiorenal end points in a trial of aliskiren for type 2 diabetes. $N$ Engl $\mathrm{J} \mathrm{Med}$ 2012:367:2204-13.

47 Kunz R, Friedrich C, Wolbers M, Mann JF. Meta-analysis: effect of monotherapy and combination therapy with inhibitors of the renin angiotensin system on proteinuria in renal disease. Ann Internal Med 2008;148:30-48.

48 Nakao N, Yoshimura A, Morita H, Takada M, Kayano T, Ideura T. Combination treatment of angiotensin-II receptor blocker and angiotensin-converting-enzyme inhibitor in non-diabetic renal disease (COOPERATE): a randomised controlled trial. Lancet 2003;361:117-24.

49 Pini P. Introducing the most wanted Lancet articles. Lancet 2003;361:1265

50 Mann JF, Schmieder RE, McQueen M, Dyal L, Schumacher H, Pogue J, et al. Renal outcomes with telmisartan, ramipril, or both, in people at high vascular risk (the ONTARGET study): a multicentre, randomised, double-blind, controlled trial. Lancet 2008;372:547-53.

51 Kunz R, Wolbers M, Glass T, Mann JF. The COOPERATE trial: a letter of concern. Lancet 2008;371:1575-6.
52 Retraction. Combination treatment of angiotensin-II receptor blocker and angiotensin-converting-enzyme inhibitor in non-diabetic renal disease (COOPERATE): a randomised controlled trial. Lancet 2009;374:1226.

53 Lakhdar R, Al-Mallah MH, Lanfear DE. Safety and tolerability of angiotensin-converting enzyme inhibitor versus the combination of angiotensin-converting enzyme inhibitor and angiotensin receptor blocker in patients with left ventricular dysfunction: a systematic review and meta-analysis of randomized controlled trials. J Card Fail 2008;14:181-8.

54 Harel Z, Gilbert C, Wald R, Bell C, Perl J, Juurlink D, et al. The effect of combination treatment with aliskiren and blockers of the renin-angiotensin system on hyperkalaemia and acute kidney injury: systematic review and meta-analysis. BMJ 2012;344:e42.

55 Sever P. VALUE: analysis of results. Lancet 2004;364:933-4; author reply 35.

56 European Medicines Agency recommends new contraindications and warnings for aliskiren-containing medicines. 2012.www.ema.europa.eu/docs/en_GB/document_library/ Press_release/2012/02/WC500122913.pdf.

57 Fried LF, Duckworth W, Zhang JH, O'Connor T, Brophy M, Emanuele N, et al. Design of combination angiotensin receptor blocker and angiotensin-converting enzyme inhibitor for treatment of diabetic nephropathy (VA NEPHRON-D). Clin J Am Soc Nephrol 2009;4:361-8.

Accepted: 2 January 2013

\section{Cite this as: BMJ 2013;346:f360}

This is an open-access article distributed under the terms of the Creative Commons Attribution Non-commercial License, which permits use, distribution, and reproduction in any medium, provided the original work is properly cited, the use is non commercial and is otherwise in compliance with the license. See: http://creativecommons.org/licenses/by$\mathrm{nc} / 2.0 /$ and http://creativecommons.org/licenses/by-nc/2.0/legalcode. 


\section{Tables}

\section{Table 1 | Characteristics of included studies}

\begin{tabular}{|c|c|c|c|c|c|c|c|c|c|}
\hline Trial name, year & Patient cohort & $\begin{array}{c}\text { No of } \\
\text { patients }\end{array}$ & $\begin{array}{l}\text { Mean } \\
\text { age } \\
\text { (years) }\end{array}$ & $\begin{array}{l}\text { Men } \\
(\%)\end{array}$ & $\begin{array}{l}\text { Follow-up } \\
\text { (weeks) }\end{array}$ & $\begin{array}{l}\text { RAS blocker } \\
\text { monotherapy }\end{array}$ & $\begin{array}{l}\text { RAS blocker } \\
\text { combination }\end{array}$ & $\begin{array}{l}\text { Risk of } \\
\text { bias }\end{array}$ & $\begin{array}{c}\text { Data } \\
\text { available }\end{array}$ \\
\hline \multicolumn{10}{|l|}{$\begin{array}{l}\text { ACE inhibitor/ARB } \\
\text { combination } v \text { RAS } \\
\text { blocker monotherapy: }\end{array}$} \\
\hline AMAZE $^{14} 2004$ & Essential hypertension & 1096 & 54 & 58 & 8 & Lisinopril & Lisinopril+candesartan & High & Safety \\
\hline Azizi et $\mathrm{al}^{15} 2000$ & $\begin{array}{l}\text { Mild to moderate } \\
\text { hypertension }\end{array}$ & 177 & NR & 64 & 6 & $\begin{array}{l}\text { Enalapril or } \\
\text { losartan }\end{array}$ & Enalapril+losartan & High & Safety \\
\hline CALM $^{16} 2001$ & $\begin{array}{l}\text { Diabetes, hypertension and } \\
\text { microalbuminuria }\end{array}$ & 197 & 60 & 65 & 24 & $\begin{array}{l}\text { Lisinopril or } \\
\text { candesartan }\end{array}$ & Lisinopril+candesartan & High & Safety \\
\hline CALM II 2005 & Hypertension and diabetes & 75 & 55 & 75 & 52 & Lisinopril & Lisinopril+candesartan & High & Safety \\
\hline $\begin{array}{l}\text { CHARM Added }{ }^{18} \\
2003\end{array}$ & $\begin{array}{l}\text { Heart failure and ejection } \\
\text { fraction } \leq 40 \%\end{array}$ & 2548 & 64 & 79 & 178 & Any ACE inhibitor & $\begin{array}{l}\text { ACE } \\
\text { inhibitor+candesartan }\end{array}$ & Low & $\begin{array}{c}\text { Efficacy and } \\
\text { safety }\end{array}$ \\
\hline Cice et $\mathrm{al}^{19} 2010$ & $\begin{array}{l}\text { Haemodialysis, heart failure } \\
\text { with ejection fraction } \leq 40 \%\end{array}$ & 332 & 63 & 54 & 156 & Any ACE inhibitor & ACE inhibitor+telmisartan & Low & $\begin{array}{c}\text { Efficacy and } \\
\text { safety }\end{array}$ \\
\hline IMPROVE $^{20} 2007$ & $\begin{array}{l}\text { High risk cardiovascular } \\
\text { disease and } \\
\text { microalbuminuria }\end{array}$ & 405 & 66 & 61 & 20 & Ramipril & Ramipril+irbesartan & High & Safety \\
\hline Kanno et al ${ }^{21} 2006$ & $\begin{array}{l}\text { Hypertension and chronic } \\
\text { kidney disease }\end{array}$ & 90 & 60 & 40 & 156 & Any ACE inhibitor & $\begin{array}{l}\text { ACE } \\
\text { inhibitor+candesartan }\end{array}$ & Low & Safety \\
\hline Kum et $\mathrm{al}^{22} 2008$ & $\begin{array}{l}\text { Chronic systolic heart } \\
\text { failure with ejection fraction } \\
<50 \%\end{array}$ & 50 & 66 & 72 & 52 & Any ACE inhibitor & ACE inhibitor+irbesartan & High & $\begin{array}{c}\text { Efficacy and } \\
\text { safety }\end{array}$ \\
\hline Mehdi et $\mathrm{al}^{23} 2009$ & $\begin{array}{l}\text { Diabetes, hypertension, and } \\
\text { albuminuria }\end{array}$ & 81 & 50 & 48 & 48 & Lisinopril & Lisinopril+losartan & High & Safety \\
\hline Ogawa et al ${ }^{24} 2007$ & $\begin{array}{l}\text { Hypertension and diabetic } \\
\text { nephropathy }\end{array}$ & 164 & 62 & 48 & 96 & $\begin{array}{l}\text { Temocapril, } \\
\text { candesartan }\end{array}$ & Temocapril+candesartan & High & Safety \\
\hline ONTARGET ${ }^{25} 2008$ & $\begin{array}{l}\text { High risk cardiovascular } \\
\text { disease }\end{array}$ & 25620 & 67 & 73 & 243 & $\begin{array}{l}\text { Ramipril or } \\
\text { telmisartan }\end{array}$ & Ramipril+telmisartan & Low & $\begin{array}{c}\text { Efficacy and } \\
\text { safety }\end{array}$ \\
\hline RESOLVD ${ }^{26} 1999$ & $\begin{array}{l}\text { Heart failure with ejection } \\
\text { fraction }<40 \%\end{array}$ & 768 & 64 & 83 & 43 & $\begin{array}{l}\text { Enalapril or } \\
\text { candesartan }\end{array}$ & Enalapril+candesartan & Low & Safety \\
\hline Ruilope et $\mathrm{al}^{27} 2000$ & $\begin{array}{l}\text { Hypertension, chronic } \\
\text { kidney disease with or } \\
\text { without proteinuria }\end{array}$ & 108 & 57 & 70 & 4 & Valsartan & Benazepril+valsartan & High & Safety \\
\hline Titan et $\left.a\right|^{28} 2011$ & Diabetic nephropathy & 56 & 58 & 63 & 16 & Enalapril & Enalapril+losartan & High & Safety \\
\hline Tonkon et $\mathrm{al}^{29} 2000$ & Chronic heart failure & 109 & 64 & 76 & 12 & Any ACE inhibitor & ACE inhibitor+irbesartan & High & Safety \\
\hline VALERIA ${ }^{30} 2008$ & $\begin{array}{l}\text { Hypertension and } \\
\text { microalbuminuria }\end{array}$ & 133 & 59 & 69 & 30 & $\begin{array}{l}\text { Lisinopril or } \\
\text { valsartan }\end{array}$ & Lisinopril+valsartan & Low & Safety \\
\hline Val-HeFT ${ }^{31} 2001$ & $\begin{array}{l}\text { NYHA class II-IV heart } \\
\text { failure }\end{array}$ & 5010 & 63 & 80 & 100 & Any ACE inhibitor & ACE inhibitor+valsartan & Low & $\begin{array}{c}\text { Efficacy and } \\
\text { safety }\end{array}$ \\
\hline V-HeFT ${ }^{32} 1999$ & $\begin{array}{l}\text { Symptomatic NYHA class } \\
\text { II-IV heart failure }\end{array}$ & 83 & 64 & 100 & 4 & Any ACE inhibitor & ACE inhibitor+valsartan & High & Safety \\
\hline VALIANT ${ }^{33} 2003$ & $\begin{array}{l}\text { Acute myocardial infarction } \\
\text { complicated by heart failure }\end{array}$ & 14703 & 65 & 69 & 107 & $\begin{array}{l}\text { Captopril or } \\
\text { valsartan }\end{array}$ & Captopril+valsartan & Low & $\begin{array}{c}\text { Efficacy and } \\
\text { safety }\end{array}$ \\
\hline White et $\left.a\right|^{34} 2007$ & $\begin{array}{l}\text { Symptomatic heart failure } \\
\text { with ejection fraction } \leq 40 \%\end{array}$ & 80 & 62 & 90 & 26 & Any ACE inhibitor & $\begin{array}{l}\text { ACE } \\
\text { inhibitor+candesartan }\end{array}$ & High & Safety \\
\hline $\begin{array}{l}\text { Yasamura et al }{ }^{35} \\
2004\end{array}$ & $\begin{array}{l}\text { Mild to moderate chronic } \\
\text { heart failure }\end{array}$ & 106 & 65 & 80 & 26 & Any ACE inhibitor & ACE inhibitor+ARB & High & Safety \\
\hline \multicolumn{10}{|l|}{$\begin{array}{l}\text { ACE inhibitor/aliskiren } \\
\text { combination } v \text { RAS } \\
\text { blocker monotherapy: }\end{array}$} \\
\hline $\mathrm{ALOFT}^{36} 2008$ & $\begin{array}{l}\text { Hypertension and NYHA } \\
\text { class II-IV heart failure }\end{array}$ & 302 & 67 & 78 & 12 & Any ACE inhibitor & ACE inhibitor+aliskiren & Low & Safety \\
\hline ASPIRE $^{37} 2011$ & $\begin{array}{l}\text { Post-myocardial infarction } \\
\text { with systolic dysfunction }\end{array}$ & 820 & 60 & 82 & 36 & Any ACE inhibitor & ACE inhibitor+aliskiren & Low & Safety \\
\hline
\end{tabular}


Table 1 (continued)

\begin{tabular}{llcccccccc} 
Trial name, year & \multicolumn{1}{c}{ Patient cohort } & $\begin{array}{c}\text { No of } \\
\text { patients }\end{array}$ & $\begin{array}{c}\text { Mean } \\
\text { age } \\
\text { (years) }\end{array}$ & $\begin{array}{c}\text { Men } \\
(\%)\end{array}$ & $\begin{array}{c}\text { Follow-up } \\
\text { (weeks) }\end{array}$ & $\begin{array}{c}\text { RAS blocker } \\
\text { monotherapy }\end{array}$ & $\begin{array}{c}\text { RAS blocker } \\
\text { combination }\end{array}$ & $\begin{array}{c}\text { Risk of } \\
\text { bias }\end{array}$ & $\begin{array}{c}\text { Data } \\
\text { available }\end{array}$ \\
Uresin et $\mathrm{al}^{38} 2007$ & $\begin{array}{l}\text { Diabetes mellitus and } \\
\text { hypertension }\end{array}$ & 837 & 59 & 59 & 8 & $\begin{array}{l}\text { Ramipril or } \\
\text { aliskiren }\end{array}$ & Ramipril+aliskiren & Low & Safety \\
\hline
\end{tabular}

ARB/aliskiren

combination $v$ RAS

blocker monotherapy:

\begin{tabular}{|c|c|c|c|c|c|c|c|c|c|}
\hline ALLAY ${ }^{39} 2009$ & $\begin{array}{l}\text { Hypertension and left } \\
\text { ventricular hypertrophy }\end{array}$ & 460 & 59 & 76 & 36 & $\begin{array}{l}\text { Losartan or } \\
\text { aliskiren }\end{array}$ & Losartan+aliskiren & Low & Safety \\
\hline $\begin{array}{l}\text { AVANTE GARDE }{ }^{40} \\
2010\end{array}$ & $\begin{array}{l}\text { Acute coronary syndrome } \\
\text { without heart failure, raised } \\
\text { natriuretic peptide }\end{array}$ & 1101 & 63 & 68 & 8 & $\begin{array}{l}\text { Valsartan or } \\
\text { aliskiren }\end{array}$ & Valsartan+aliskiren & Low & Safety \\
\hline AVOID $^{41} 2008$ & $\begin{array}{l}\text { Hypertension and diabetic } \\
\text { nephropathy }\end{array}$ & 599 & 62 & 71 & 24 & Losartan & Losartan+aliskiren & Low & Safety \\
\hline $\begin{array}{l}\text { Drummond et } \mathrm{al}^{42} \\
2011\end{array}$ & $\begin{array}{l}\text { Diabetes mellitus and } \\
\text { hypertension }\end{array}$ & 363 & 57 & 54 & 12 & Valsartan & Valsartan+aliskiren & Low & Safety \\
\hline Oparil et $\mathrm{al}^{43} 2007$ & Hypertension & 1797 & 52 & 61 & 8 & $\begin{array}{l}\text { Valsartan or } \\
\text { aliskiren, }\end{array}$ & Valsartan+aliskiren & Low & Safety \\
\hline Pool et al ${ }^{44} 2007$ & $\begin{array}{l}\text { Mild to moderate } \\
\text { hypertension }\end{array}$ & 1123 & 56 & 56 & 8 & $\begin{array}{l}\text { Valsartan or } \\
\text { aliskiren }\end{array}$ & Valsartan+aliskiren & Low & Safety \\
\hline VANTAGE ${ }^{45} 2010$ & Stage 2 hypertension & 451 & 57 & 51 & 8 & Valsartan & Valsartan+aliskiren & High & Safety \\
\hline
\end{tabular}

ACE inhibitor or

ARB/aliskiren

combination $v$ RAS

blocker monotherapy:

\begin{tabular}{llllllll}
\hline ALTITUDE $^{46} 2012$ & Diabetic nephropathy & 8561 & 65 & 68 & 139 & Aliskiren & $\begin{array}{l}\text { ACE inhibitor or } \\
\text { ARB+aliskiren }\end{array}$ \\
\hline
\end{tabular}

$\mathrm{ACE}=$ angiotensin converting enzyme; $\mathrm{ARB}=$ angiotensin receptor blocker; RAS=renin-angiotensin system; NR=not recorded; NYHA=New York Heart Association. 
Table 2/ Safety outcomes between different drug combinations for dual blockade of the renin-angiotensin system (RAS) compared with monotherapy

\begin{tabular}{|c|c|c|c|}
\hline RAS blocker combination $v$. monotherapy & Relative risk ( 9 & $5 \% \mathrm{Cl}$ ), $\mathrm{P}$ value & Interaction $\mathbf{P}$ value \\
\hline ACE inhibitors+angiotensin receptor blockers: & ACE inhibitors & Angiotensin receptor blockers & \\
\hline Hyperkalaemia & 1.83 (1.35 to 2.50$), 0.0001$ & 1.34 (0.86 to 2.09$), 0.19$ & 0.26 \\
\hline Hypotension & $2.02(1.46$ to 2.80$),<0.001$ & 1.44 (1.04 to 2.01$), 0.03$ & 0.15 \\
\hline Renal failure & 1.55 (1.23 to 1.96$), 0.0002$ & 1.15 (0.92 to 1.43$), 0.22$ & 0.07 \\
\hline Withdrawal owing to drug related adverse events & 1.21 (1.16 to 1.26$),<0.001$ & 1.39 (1.14 to 1.70$), 0.001$ & 0.18 \\
\hline ACE inhibitors+aliskiren: & ACE inhibitors & Aliskiren & \\
\hline Hyperkalaemia & 1.70 (1.11 to 2.58$), 0.01$ & 2.55 (1.00 to 6.46$), 0.05$ & 0.44 \\
\hline Hypotension & 1.97 (1.17 to 3.30$), 0.02$ & No studies available & NA \\
\hline Renal failure & 1.75 (0.92 to 3.34$), 0.09$ & 0.34 (0.04 to 3.24$), 0.35$ & 0.16 \\
\hline Withdrawal owing to drug related adverse events & 0.97 (0.34 to 2.74$), 0.95$ & 0.56 (0.21 to 1.48$), 0.24$ & 0.45 \\
\hline Angiotensin receptor blockers+aliskiren: & Angiotensin receptor blockers & Aliskiren & \\
\hline Hyperkalaemia & 1.40 (1.02 to 1.91$), 0.04$ & 1.49 (0.83 to 2.68$), 0.18$ & 0.86 \\
\hline Hypotension & $1.62(0.70$ to 3.74$), 0.26$ & 1.02 (0.66 to 1.56$), 0.94$ & 0.34 \\
\hline Renal failure & $1.13(0.52$ to 2.47$), 0.76$ & 1.02 (0.36 to 2.93$), 0.97$ & 0.88 \\
\hline Withdrawal owing to drug related adverse events & 1.06 (0.79 to 1.43$), 0.70$ & 1.19 (0.54 to 2.66$), 0.67$ & 0.79 \\
\hline
\end{tabular}

$\mathrm{ACE}=$ angiotensin converting enzyme; $\mathrm{NA}=$ not applicable. 


\section{Figures}

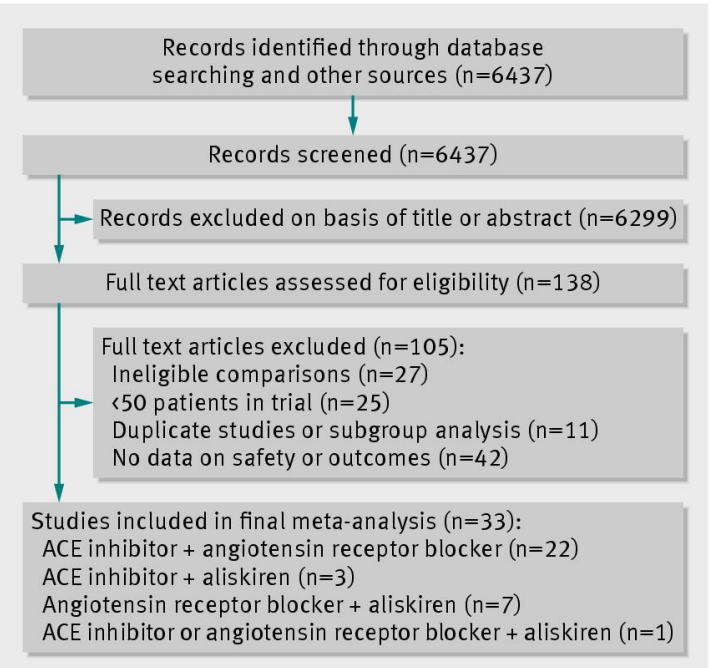

Fig 1 Selection of studies. ACE=angiotensin converting enzyme inhibitor

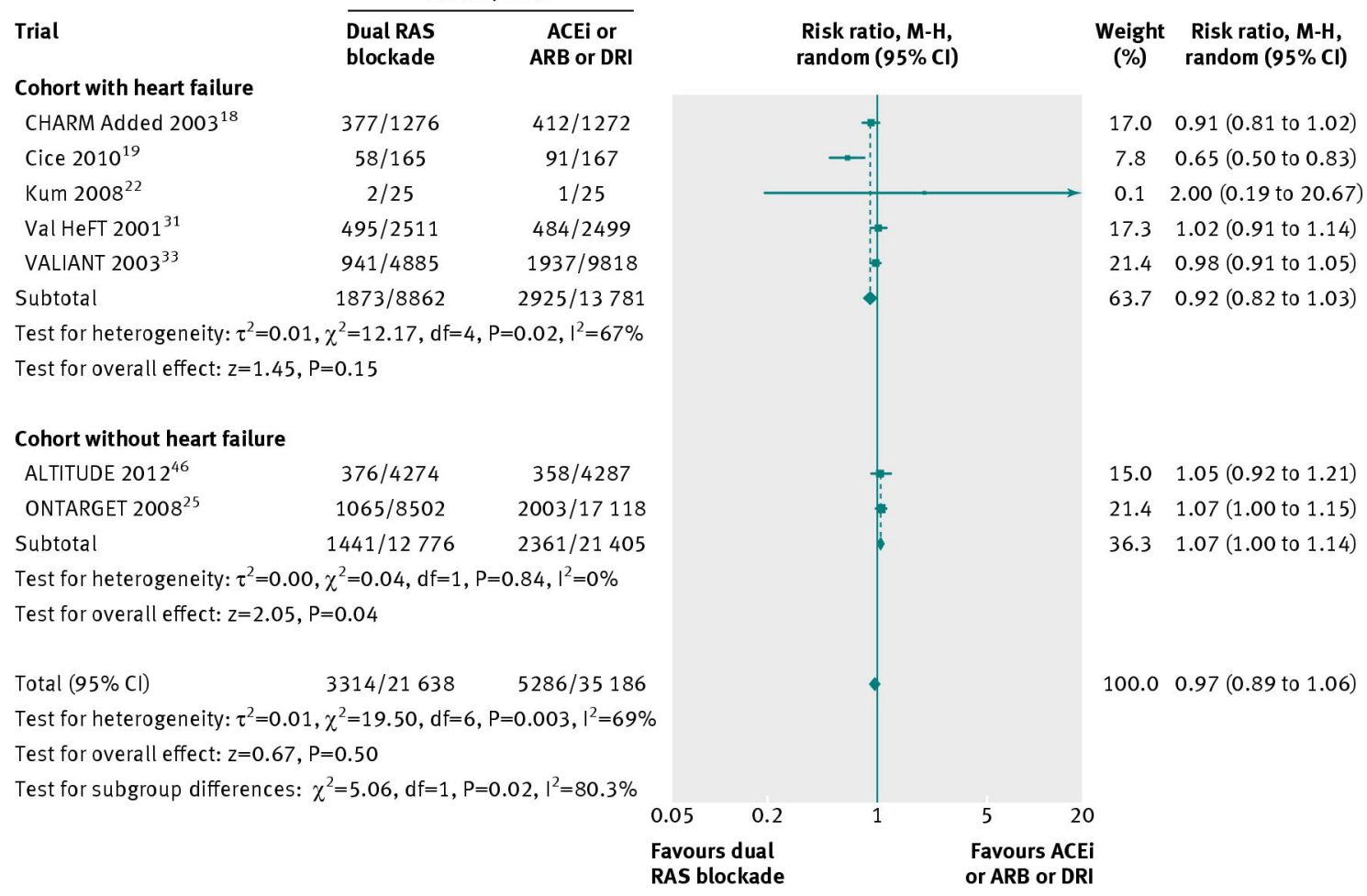

Fig 2 Comparison of dual blockade of the renin-angiotensin system (RAS) with monotherapy for all cause mortality. Error bars represent $95 \%$ confidence intervals and data marker sizes indicate sample sizes of cohorts. $\mathrm{ACEi}=$ angiotensin converting enzyme inhibitor; $A R B=a n g i o t e n s i n$ receptor blocker; DRI=direct renin inhibitor, $\mathrm{M}-\mathrm{H}=$ Mantel-Haenszel 


\begin{tabular}{|c|c|c|}
\hline \multirow[b]{2}{*}{ Trial } & \\
\hline & $\begin{array}{l}\text { Dual RAS } \\
\text { blockade }\end{array}$ & $\begin{array}{c}\text { ACEi or } \\
\text { ARB or DRI }\end{array}$ \\
\hline \multicolumn{3}{|l|}{ Cohort with heart failure } \\
\hline CHARM Added $2003^{18}$ & $302 / 1276$ & $347 / 1272$ \\
\hline Cice $2010^{19}$ & $50 / 165$ & $73 / 167$ \\
\hline Kum $2008^{22}$ & $1 / 25$ & $1 / 25$ \\
\hline VALIANT $2003^{33}$ & $827 / 4885$ & $1657 / 9818$ \\
\hline Subtotal & $1180 / 6351$ & $2078 / 11282$ \\
\hline \multicolumn{3}{|c|}{ Test for heterogeneity: $\tau^{2}=0.01, \chi^{2}=8.36, d f=3, P=0.04, I^{2}=64 \%$} \\
\hline \multicolumn{3}{|c|}{ Test for overall effect: $z=1.47, P=0.14$} \\
\hline \multicolumn{3}{|c|}{ Cohort without heart failure } \\
\hline ALTITUDE $2012^{46}$ & $246 / 4274$ & $215 / 4287$ \\
\hline ONTARGET $2008^{25}$ & $1386 / 8502$ & $2835 / 17118$ \\
\hline Subtotal & $1632 / 12776$ & $3050 / 21405$ \\
\hline \multicolumn{3}{|c|}{ Test for heterogeneity: $\tau^{2}=0.01, \chi^{2}=2.58, \mathrm{df}=1, \mathrm{P}=0.11, \mathrm{I}^{2}=61 \%$} \\
\hline \multicolumn{3}{|c|}{ Test for overall effect: $z=0.51, P=0.61$} \\
\hline Total $(95 \% \mathrm{Cl})$ & $2812 / 19127$ & $5128 / 32687$ \\
\hline \multicolumn{3}{|c|}{ Test for heterogeneity: $\tau^{2}=0.01, \chi^{2}=12.18, d f=5, P=0.03,\left.\right|^{2}=59 \%$} \\
\hline \multicolumn{3}{|c|}{ Test for overall effect: $z=0.87, P=0.38$} \\
\hline \multicolumn{3}{|c|}{ Test for subgroup differences: $\chi^{2}=2.06, d f=1, P=0.15, I^{2}=51.4 \%$} \\
\hline
\end{tabular}

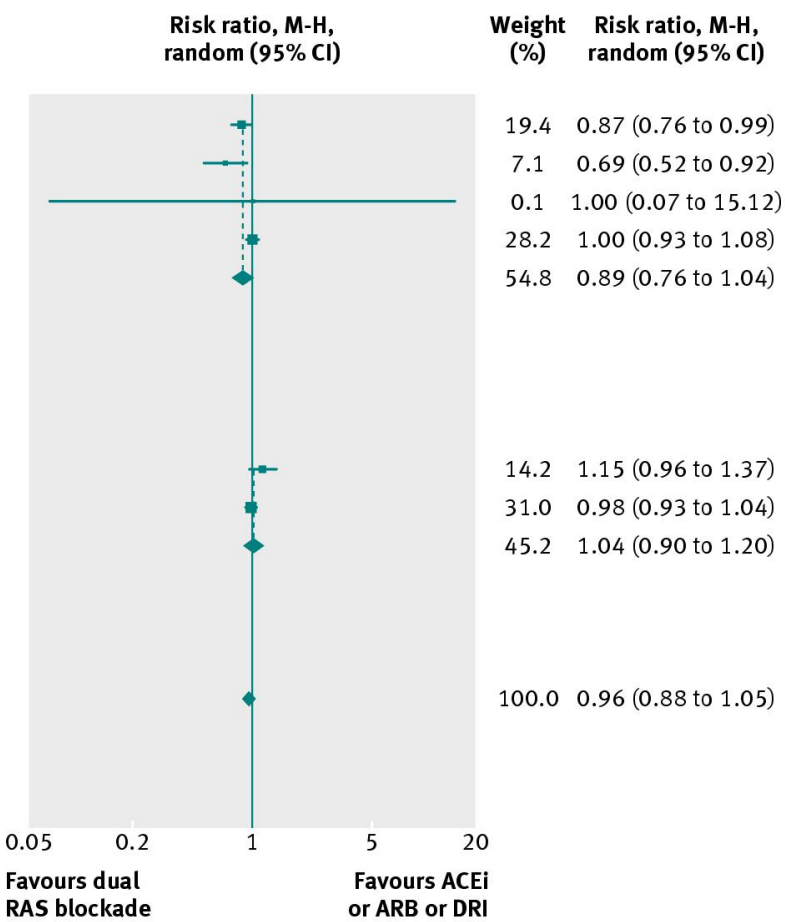

Fig 3 Comparison of dual blockade of the renin-angiotensin system (RAS) with monotherapy for cardiovascular mortality. $\mathrm{ACEi}=$ angiotensin converting enzyme inhibitor; $\mathrm{ARB}=$ angiotensin receptor blocker; $\mathrm{DRI}=$ direct renin inhibitor, $\mathrm{M}-\mathrm{H}=$ Mantel-Haenszel

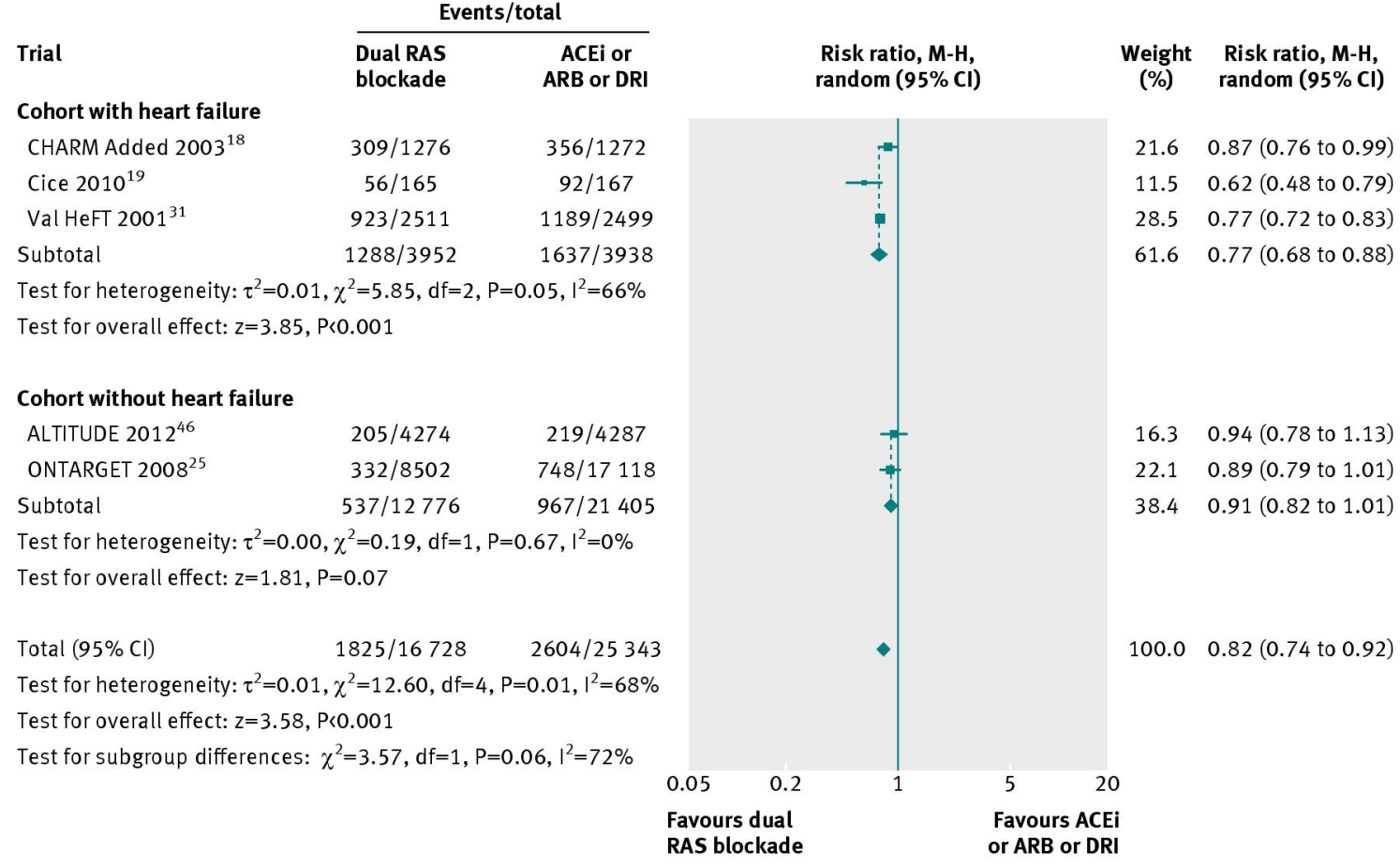

Fig 4 Comparison of dual blockade of the renin-angiotensin system (RAS) with monotherapy for admissions to hospital for heart failure. $\mathrm{ACE} i=$ angiotensin converting enzyme inhibitor; $\mathrm{ARB}=$ angiotensin receptor blocker; $\mathrm{DRI}=$ direct renin inhibitor, $\mathrm{M}-\mathrm{H}=$ Mantel-Haenszel 


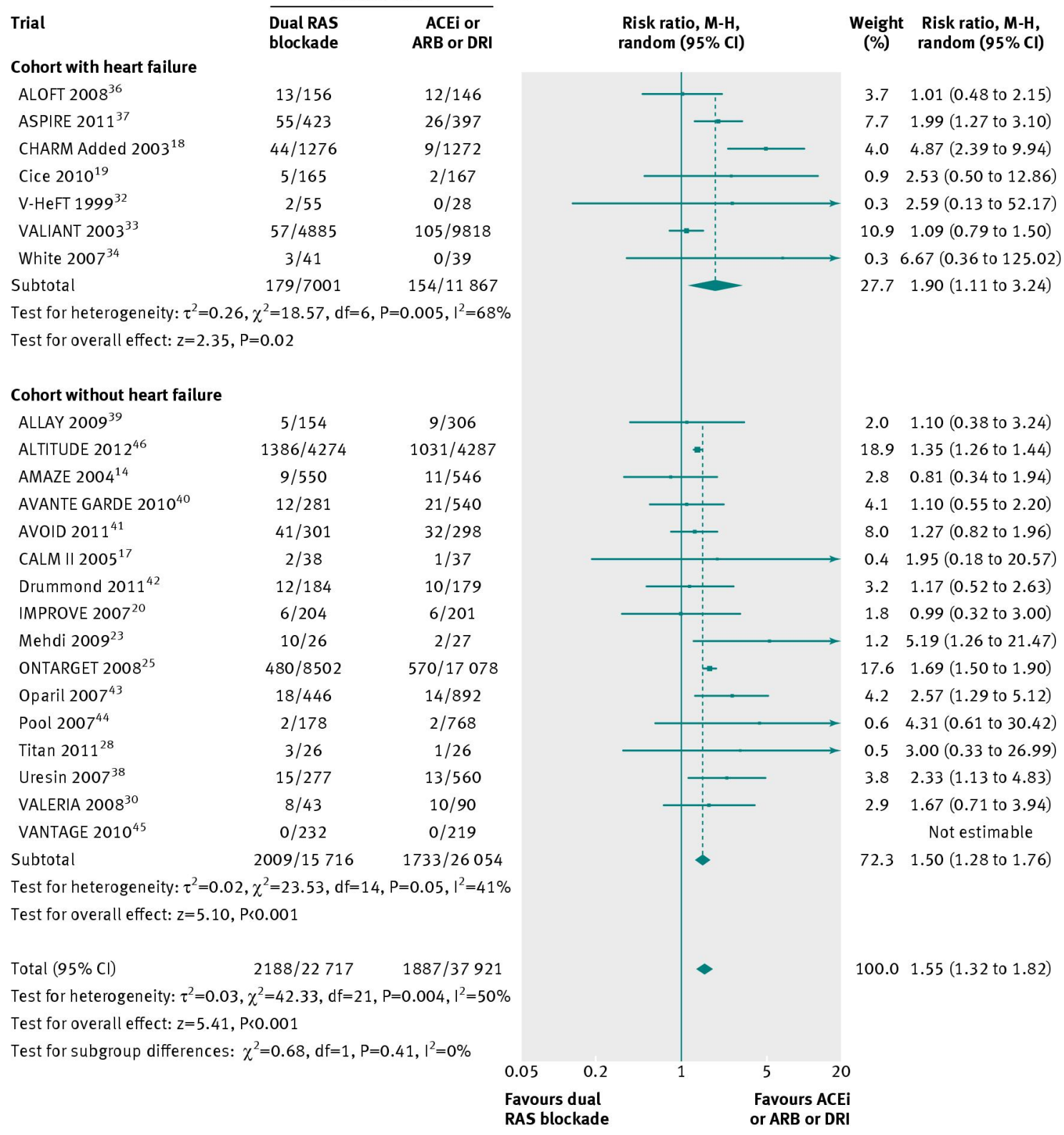

Fig 5 Comparison of dual blockade of the renin-angiotensin system (RAS) with monotherapy for hyperkalaemia. $\mathrm{ACE}=$ =angiotensin converting enzyme inhibitor; $\mathrm{ARB}=$ angiotensin receptor blocker; $\mathrm{M}-\mathrm{H}=\mathrm{Mantel}$-Haenszel 


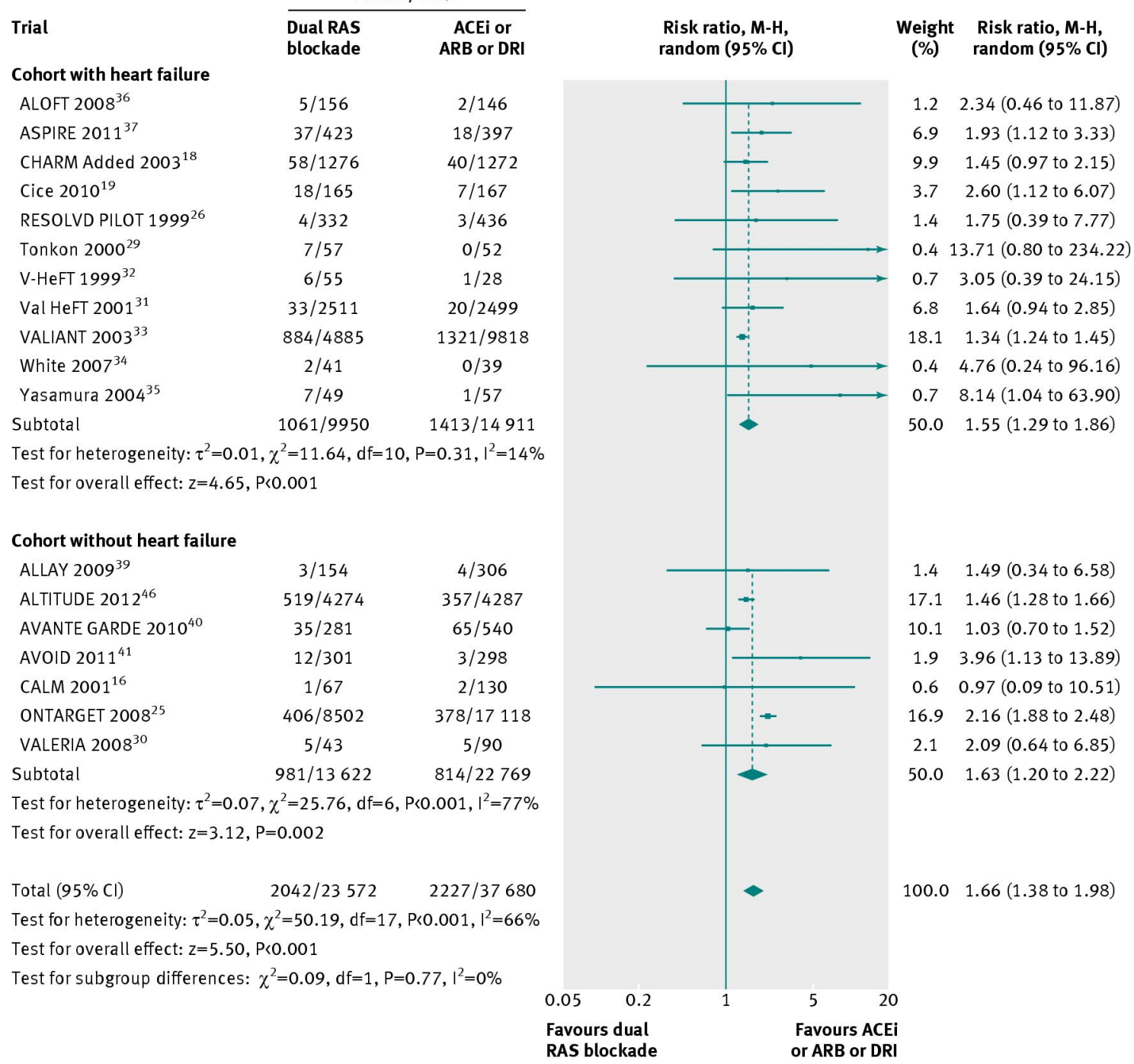

Fig 6 Comparison of dual blockade of the renin-angiotensin system (RAS) with monotherapy for hypotension, $\mathrm{ACEi}=$ angiotensin converting enzyme inhibitor; $\mathrm{ARB}=$ angiotensin receptor blocker; $\mathrm{DRI}=$ direct renin inhibitor, $\mathrm{M}-\mathrm{H}=$ Mantel-Haenszel 


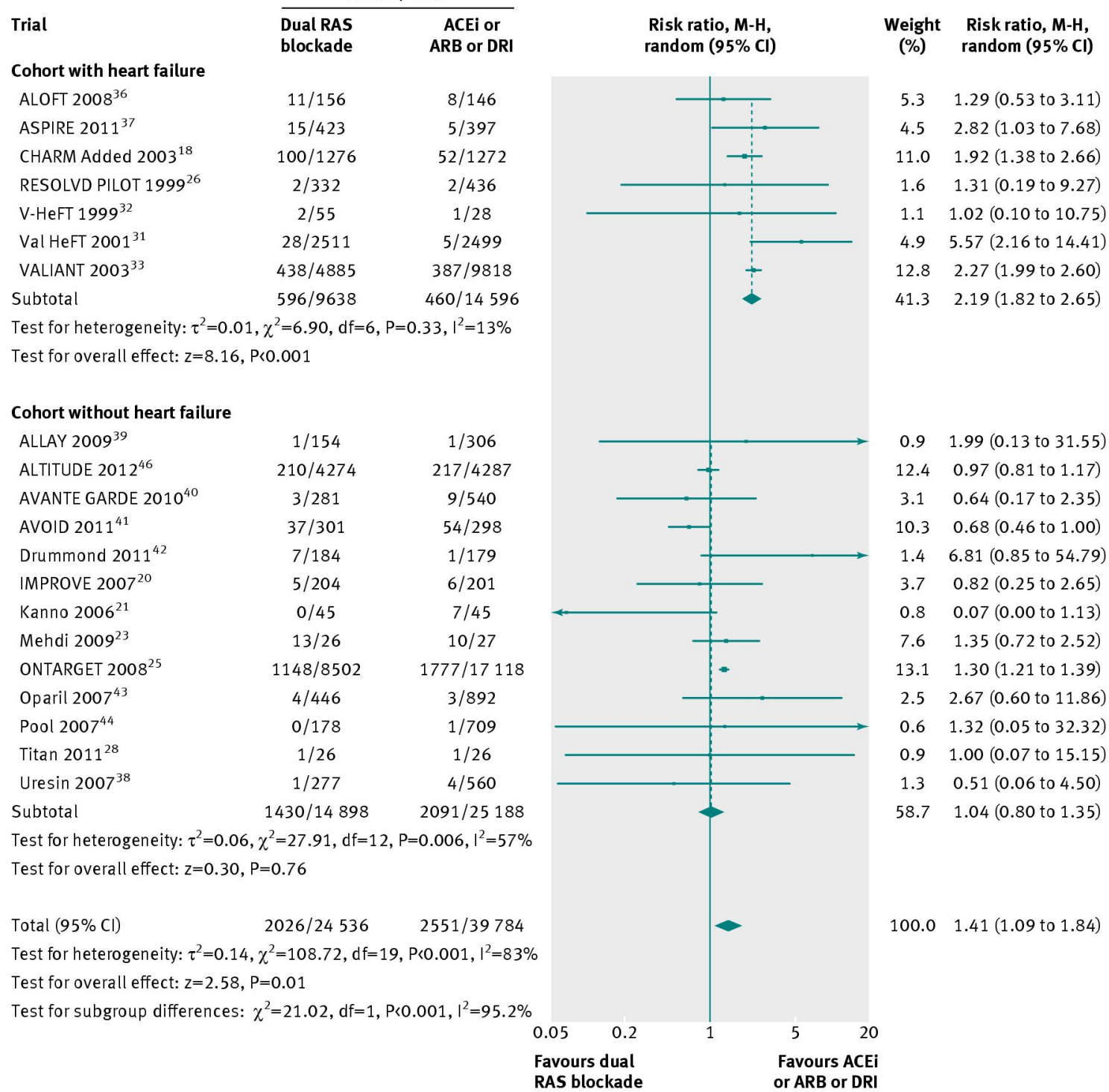

Fig 7 Comparison of dual blockade of the renin-angiotensin system (RAS) with monotherapy for renal failure. $A C E i=a n g i o t e n s i n$ converting enzyme inhibitor; $A R B=$ angiotensin receptor blocker; $D R I=d i r e c t$ renin inhibitor, $\mathrm{M}-\mathrm{H}=$ Mantel-Haenszel 


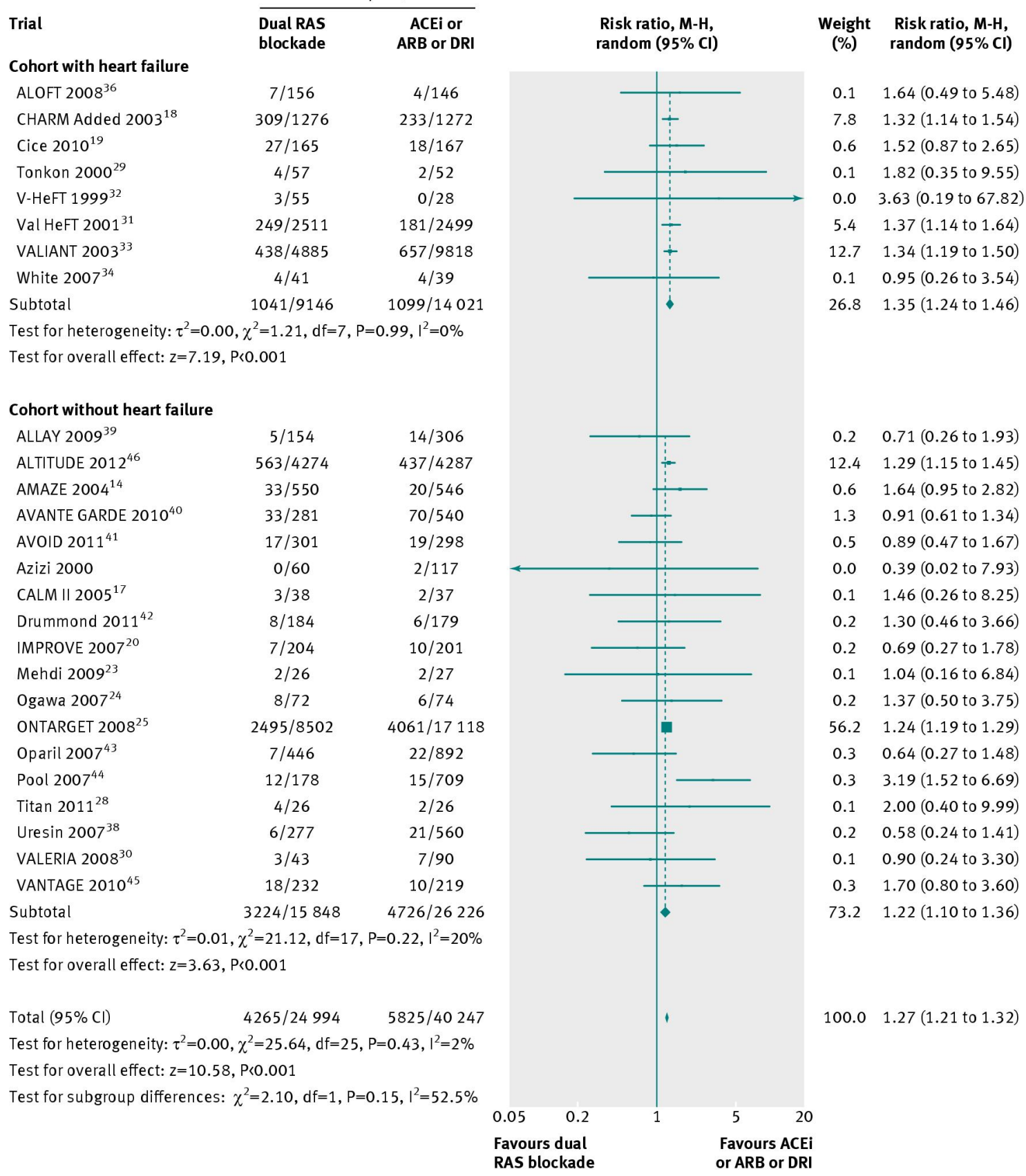

Fig 8 Comparison of dual blockade of the renin-angiotensin system (RAS) with monotherapy for withdrawal owing to drug related to adverse events 